\title{
ANALISIS DAMPAK KABUT ASAP KARHUTLA TERHADAP GANGGUAN KESEHATAN MENTAL
}

\author{
Putra Mulia $^{1}$, Nofrizal ${ }^{2}$, Wan Nishfa Dewi ${ }^{3}$ \\ $\mathbf{1}_{\text {Mahasiswa Pascasarjana Program Studi Ilmu Lingkungan, Universitas Riau }}$ \\ PSIL Universitas Riau Jalan Pattimura No 9 Pekanbaru Riau Kode Pos 28131 Indonesia \\ ${ }^{2}$ Dosen Pascasarjana Ilmu Lingkungan Universitas Riau \\ ${ }^{3}$ Dosen KJFD KMB, Fakultas Keperawatan Universitas Riau Jalan Pattimura No 9 Gedung G \\ Pekanbaru Riau Kode Pos 28131 Indonesia \\ Email : putramul@gmail.com
}

\section{Diterima: April 2021, Diterbitkan: Juni 2021}

\begin{abstract}
Abstrak
Kebakaran hutan dan lahan di Indonesia pada Tahun 2019 telah menyebabkan bencana kabut asap dan kota Pekanbaru menjadi salah satu wilayah yang terdampak. Penelitian ini bertujuan untuk menganalisis dampak kesehatan mental akibat bencana kabut asap. Data yang dikumpulkan adalah data harian ISPU dan kunjungan pasien ke RSJ Tampan dengan stres, ansietas dan PTSD. Gangguan kesehatan mental dianalisis dengan secara deskriptif. Hasil penelitian menunjukkan ISPU tertinggi yaitu 374 (sangat tidak sehat). Dari hasil penelitian, tidak ditemukan peningkatan kasus stres akut, kecemasan dan PTSD pada periode bencana kabut asap Tahun 2019. Berdasarkan penelitian dapat disarankan kepada peneliti selanjutnya, perlu melakukan studi kohort lanjutan terkait dampak kebakaran hutan dan lahan terhadap risiko gangguan stres, kecemasan dan PTSD.
\end{abstract}

Kata kunci: bencana, kabut asap, ISPU, gangguan kesehatan mental

\begin{abstract}
Forest and land fires in Indonesia on 2019, has caused haze disaster. Pekanbaru is one of the affected cities. The purpose of the study was to analyze the effect of pollutant exposure towards mental health problems. The data was collected using daily Air Quality Index (AQI) and patient visited to Tampan Psychiatric Hospital with complaints of stress, anxiety and PTSD during the 2019 haze disaster period. The analysis of mental health effect due to pollutant exposure was analyzed descriptively. Concentration of particulate matter with diameters less than or equal to 10 micrometer reached 374 point (very unhealthy). This study found that there was no increase in the number of cases of acute stress, anxiety, and PTSD during the haze disaster period. Based on this finding, it is suggested for further study that focus on it cohort studies which related to the impact of forest and land fires on mental health problems.
\end{abstract}

Keywords: disaster, haze, AQI, mental health

\section{PENDAHULUAN}

Selama Tahun 2019, kebakaran hutan dan lahan di Indonesia telah mencapai 1,6 juta hektare, dan 494.450 hektare diantaranya terjadi di lahan dan hutan gambut atau setara sekitar 30 persen (KemenLH, 2019). Sementara itu, di Provinsi Riau, kebakaran hutan dan lahan mencapai luas hingga 75.871 ha, yang paling banyak terjadi di lahan gambut mencapai 70 persen dari keseluruhan area yang terbakar (BNPB, 2019).

Kebakaran hutan dan lahan tidak hanya mempengaruhi wilayah yang terbakar saja, namun juga menjangkau wilayah lain diluar areal kebakaran. Hal ini disebabkan, kebakaran menimbulkan kabut asap tebal yang jangkauannya luas. Sebaran kabut asap dapat mencapai wilayah perkotaan dan pemukiman warga 
yang menyebabkan perubahan kualitas udara sehingga terjadi pencemaran udara.

Kualitas udara yang tidak sehat berpotensi menimbulkan gangguan kesehatan manusia. Masalah kesehatan yang timbul akibat asap tersebut terutama terjadi pada individu yang berisiko, diantaranya pasien dengan gangguan jantung dan pernapasan, kelompok usia lanjut, ibu hamil dan menyusui serta balita (Susanto, 2019). Selain menimbulkan gangguan fisik, beberapa penelitian menemukan hubungan antara kualitas udara yang tidak sehat dengan gangguan kesehatan mental.

Penelitian oleh Lim et al., (2012), polutan berupa PM10, $\mathrm{NO}^{2}$ dan $\mathrm{O}^{3}$ berhubungan erat dengan gejala emosional dengan diikuti gejala somatik dan afektif pada lansia. Peningkatan kadar tiga polutan tersebut menyebabkan gejala depresi. Efek depresi ini juga bisa terjadi pada wanita usia dewasa (Kioumourtzoglou, 2017). Menurut Tan et al., (2018), bencana asap menyebabkan perubahan signifikan terhadap hemodinamik otak pada individu rentan yang menyebabkan timbulnya berbagai gejala psikosomatik. Bencana asap yang terjadi pada Tahun 2015 di Kota Pekanbaru dilaporkan mengakibatkan terjadinya peningkatan stres pada anak-anak usia sekolah, yang ditunjukkan dalam bentuk kegelisahan, mengeluh sakit di dada, mimpi buruk, mengigau dan demam tinggi. Selain itu beberapa orang tua menyebutkan bahwa anaknya sering berperilaku sulit/ tidak kooperatif dan ketakutan sebagai dampak dari resiko terpapar asap (Antara, 2015). Berdasarkan uraian latar belakang tersebut maka peneliti bertujuan untuk menganalisis kualitas ISPU Kota Pekanbaru, menganalisis dampak kabut asap karhutla terhadap gangguan kesehatan fisik dan menganalisis dampak kabut asap karhutla terhadap gangguan kesehatan mental selama bencana karhutla Tahun 2019 di Kota Pekanbaru.

\section{METODE PENELITIAN}

Penelitian ini dilakukan di Kota Pekanbaru, pada bulan Mei - Agustus 2020 dengan menggunakan data yang tercatat selama periode kabut asap Juli - Oktober 2019. Pengambilan data parameter kualitas ISPU diambil dari data Laboratorium Udara DLHK Kota Pekanbaru. Data gangguan kesehatan mental didapat dari angka kunjungan pasien rawat jalan di Rumah Sakit Jiwa (RSJ) Tampan dengan gangguan ansietas, stres akut dan Post Trauma Stres Disorder (PTSD).

Data ISPU dianalisis secara deskriptif dengan membuat grafik perbandingan jumlah polutan perbulan. Data jenis penyakit dikumpulkan berdasarkan data rekam medis RSJ Tampan Tahun 2019. Data yang didapat ditabulasi dan dianalisis secara deskriptif menggunakan software Microsoft Excel.

\section{HASIL DAN PEMBAHASAN}

\section{Kualitas ISPU Kota Pekanbaru}

Hasil penelitian pada Tabel 1 . menunjukkan nilai rata-rata ISPU paling rendah tercatat bulan Oktober yaitu 26 (kategori baik) dan tertinggi pada bulan September yaitu 374 (kategori berbahaya). Tingkat pencemaran udara di bulan September pada tingkat yang sangat tidak sehat dan berbahaya. Dampak yang mungkin timbul adalah gangguan kesehatan pada sejumlah segmen populasi yang terpapar dan secara umum dapat merugikan kesehatan yang serius pada populasi rentan (KemenLH, 1997).

Tabel 1.

Kadar ISPU Juli - Oktober di Pekanbaru

\begin{tabular}{cccc}
\hline \multirow{3}{*}{ Periode Bulan } & \multicolumn{3}{c}{ Kadar ISPU } \\
\cline { 2 - 4 } & $\begin{array}{c}\text { Rentang } \\
\text { ISPU Harian }\end{array}$ & $\begin{array}{c}\text { Rata-rata ISPU } \\
\text { (per hari) }\end{array}$ & $\begin{array}{c}\text { Rata-rata } \\
\text { Kategori ISPU } \\
\text { (perhari) }\end{array}$ \\
\hline Juli & $31-61$ & $42,10 \pm 8,001 /$ & Baik \\
Agustus & $31-90$ & $59,84 \pm 13,995$ & Sedang \\
September & $39-374$ & $113,53 \pm$ & Tidak Sehat \\
Oktober & $26-67$ & 41,437 & Baik \\
\hline
\end{tabular}

Peningkatan kadar ISPU pada rentang bulan Juli - Oktober 2019 disebabkan karena kebakaran hutan dan lahan di 
beberapa wilayah di Provinsi Riau dan sekitarnya. Tercatat selama periode Juli Oktober 2019 luas kebakaran hutan dan lahan di Provinsi Riau berjumlah 6.445 ha, meningkat dibandingkan Januari - Juni sebanyak 3.272 ha (BPBD Provinsi Riau, 2019).

Pada periode bulan Maret hingga Mei yang berarti peralihan antara musim penghujan dan musim kemarau, jumlah hotspot tercatat lebih sedikit, jika dibandingkan dengan musim kemarau yang terjadi pada periode bulan Juni hingga Agustus. Dari bulai Juli hingga September, jumlah hotspot meningkat drastis, yang berkaitan dengan berkurangnya curah hujan dan meningkatnya temperatur udara. Jumlah hotspot paling banyak terjadi pada bulan September meningkat tajam dipandingkan bulan Juli (Aflahah et al., 2018).

Menurut Syaufina dan Sukmana (2008), penurunan jumlah curah hujan berkaitan erat dengan penurunan jumlah hotspot pada bulan-bulan tertentu. Pada bulan Oktober hingga Desember, curah hujan meningkat yang menyebabkan jumlah hotspot berkurang drastis. Sebaliknya, pada periode bulan Mei hingga September dengan tingkat kelembaban lebih tinggi dan curah hujan rendah, terdapat titik hotspot dengan jumlah yang tinggi. Peningkatan jumlah hotspot merupakan indikasi intensitas kebakaran hutan dan lahan juga akan meningkat. Jika potensi kebakaran semakin meningkat, maka akan berdampak dengan meningkatnya jumlah kabut asap yang naik ke atmosfer.

\section{Dampak Kabut Asap Karhutla terhadap Gangguan Kesehatan Mental}

Menurut Kementerian Kesehatan (2016), kabut asap baik secara langsung maupun tidak langsung dapat menimbulkan gangguan stres pada manusia. Hal ini didasarkan dengan adanya hubungan antara kualitas lingkungan yang mempengaruhi kenyamananan dan persepsi seseorang dalam berperilaku. Hubungan interaksi manusia dan lingkungan yang mempengaruhi psikologi manusia dijelaskan menggunakan Teori Stres Lingkungan (Helmi, 1999). Teori ini menjabarkan 3 pendekatan dalam stres yaitu stres sebagai stresor, stres sebagai respon/ reaksi dan stres sebagai proses. Stresor merupakan sumber atau stimulus yang mengancam kesejahteraan seseorang, misalnya suara bising, panas atau kepadatan tinggi. Respon stres adalah reaksi yang melibatkan komponen emosional, pikiran, fisiologis dan perilaku. Proses merupakan proses transaksi antara stresor dengan kapasitas diri. Oleh karenanya, istilah stres tidak hanya merujuk pada sumber stres, respon terhadap sumber stres saja, tetapi keterkaitan antara ketiganya (Prawitasari, 1989 dalam Helmi, 1999).

Interaksi antara sumber stres dengan kemampuan seseorang (kapasitas diri) akan menentukan bentuk dan kualitas reaksi stres. Jika sumber stres lebih besar daripada kapasitas diri maka stres negatif akan muncul, sebaliknya jika sumber tekanan sama dengan atau kurang sedikit dari kapasitas diri maka stres positif akan muncul. Dalam kaitannya dengan stres lingkungan, ada pengaruh antara karakteristik lingkungan dengan karakteristik individu yang menentukan apakah situasi yang menekan tersebut menimbulkan stres atau tidak. Udara panas bagi sebagian orang menurunkan kinerja, tetapi bagi orang lain yang terbiasa tinggal di daerah gurun, udara panas tidak menghambat kinerja (Helmi, 1999). Menurut IDAI (2015) kondisi darurat asap dapat menimbulkan stres dan kecemasan pada anak yang bermanifestasi sebagai gelisah, mengeluh sakit, mimpi buruk, regresi, perilaku sulit/tidak kooperatif, ketakutan dan lainnya

Analisis dan pembahasan dampak polutan kabut asap terhadap gangguan kesehatan mental pada penelitian ini dibatasi pada diagnosa stres akut (F43.0), Post Trauma Stress Disorder (F43.1) dan kecemasan (F41.1). 


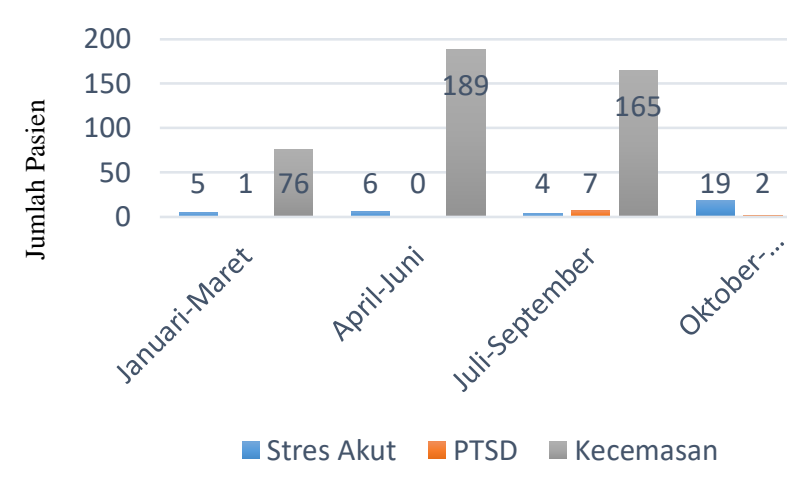

Gambar 1
Kunjungan Rawat Jalan Pasien RSJ Tampan

Hasil pengumpulan data berdasarkan Gambar 1. menunjukkan bahwa masyarakat yang didiagnosis mengalami kecemasan tertinggi pada periode April Juni (189 kasus), pasien yang mengalami stres akut tertinggi pada Oktober Desember (19 kasus) dan PTSD tertinggi pada Juli - September (7 kasus) Tahun 2019.

Berdasarkan hasil penelitian tidak terdapat peningkatan kasus stres, kecemasan dan PTSD. Hasil penelitian ini berbeda dengan penelitian oleh Tan, et al (2109) yang menyatakan bahwa kabut asap menimbulkan perubahan pada sistem hemodinamik otak pada individu rentan, yang menyebabkan berbagai gejala psikosomatik. Hasil penelitian berbeda juga dikemukakan oleh Hsien-Jien dan Lin (2008) yang menyatakan terjadi peningkatan gangguan emosional seperti depresi, kelelahan non-fisik, kecemasan, ketakutan, kesulitan untuk istirahat, agitasi, mudah marah dan tidak selera makan pada staf dan mahasiswa di Malaysia akibat bencana kabut asap.

Menurut Suryani (2017) bencana asap yang umum dan rutin terjadi di Provinsi Riau tidak menimbulkan dampak secara fisik dan psikis yang mudah terlihat. Sehingga tidak sampai menimbulkan respon traumatik baik pada individu maupun masyarakat. Hasil penelitian ini dapat disebabkan masyarakat telah beradaptasi dengan bencana kabut asap yang berulang kali terjadi sehingga simptom traumatik tidak terlihat jelas dan sulit dideteksi. Bentuk adaptasi yang dilakukan diantaranya adanya solidaritas dan partisipasi masyarakat untuk menolong korban bencana aspa dengan memberikan sumbangan masker, alat pembersih udara dan obat-obatan. Sebagian masyarakat juga telah mempersiapkan diri dan mengungsikan anggota keluarganya yang beresiko ke wilayah yang tidak terpapar kabut asap, seperti ke Provinsi Sumatera Barat. Walaupun tingkat kepatuhan masyarakat untuk memakai masker masih kurang baik, namun promosi kesehatan masif dilakukan oleh Dinas Kesehatan dengan juga mengaktifkan Puskesmas 24 jam.

Yuwanto et al., mengemukakan suatu perspektif yang bersifat universal mengenai respon individu dan komunitas terhadap bencana. Pasca terjadinya bencana, respon perilaku mengikuti fase heroic, fase honeymoon, fase disillusionment dan fase rekonstruksi. Fase respon perilaku ini berkaitan dengan faktor tekanan yang dialami karena bencana. Pada fase heroic tampak bentuk perilaku berbagai pihak yang menunjukkan kepedulian bagi penyintas bencana.

Penjelasan yang lebih mendalam terkait fase heroic ini juga dapat disebabkan pengaruh media massa. Menurut Aryanata dan Utami (2019) media massa memberi andil dalam mengkonstruksikan pemikiran khalayak atas bencana. Media diketahui memiliki kekuatan besar dalam menyebarkan informasi sekaligus membentuk opini dan sikap khalayak atas suatu peristiwa. Narasi media tentang penderitaan korban dan kedahsyatan bencana, baik dalam media cetak maupun media daring, dapat berkontribusi pada konstruksi pemahaman individu atas bencana maupun respon mereka dalam menyikapi bencana dan korban. Menurut Daniyati (2016), penyajian berita oleh media massa 
berpengaruh signifikan terhadap sikap kepedulian sosial masyarakat.

Perkembangan teknologi dan informasi yang pesat dekade ini berpengaruh pada karakteristik komunikasi sosial masyarakat, yang secara tidak langsung juga berperan dalam kampanye lingkungan, salah satunya berkaitan dengan isu bencana. Kampanye lingkungan lebih banyak dipromosikan menggunakan media sosial dibandingkan media massa mainstream. Menurut Hariyani (2016), keterlibatan peran jaringan di media sosial mempengaruhi efektifitas kampanye melawan asap, serta hubungan sosial antar organisasi yang tergabung dalam aliansi gerakan melawan asap terbentuk berdasarkan jaringan perasaan/sentiment.

Selanjutnya penyintas bencana masuk pada fase yang disebut dengan fase honeymoon. Pada fase honeymoon penyintas bencana mulai merasakan kenyamanan dari perhatian dan banyaknya bantuan yang datang. Namun layaknya bulan madu yang pengalamannya nyaris menyerupai kurva, durasinya juga tidak permanen. Kemudian penyintas bencana masuk pada fase disillusionment, yaitu persepsi ketidaknyamanan untuk melakukan aktivitas layaknya kehidupan sebelum bencana. Untuk menyiasati diri dan lingkungannya, individu dan komunitas tersebut melakukan fase rekonstruksi, yaitu berupaya untuk dapat kembali menjalankan fungsi-fungsi kehidupan seperti layaknya hidup sebelum bencana. Usaha untuk bangkit melakukan rekonstruksi ini disebut sebagai daya lenting atau resiliensi penyintas bencana (Yuwanto et al., 2018).

Perspektif yang lebih kontekstual terkait dengan respon terhadap bencana juga dapat dilihat dari ragam respon yang teridentifikasi sebagai adanya peran nilai budaya lokal yang dimiliki warga setempat dalam merespon bencana alam yang mereka alami (Rozi, 2017; Rudianto, 2017; Rakhman dan Kuswardani, 2012; Novianty, 2011). Koentjoro dan Andayani
(2007) menyebutkan terdapat kemungkinan munculnya pemahaman khas penyintas bencana yang kontekstual dengan budaya asalnya dalam merespon bencana yang menimpa.

Respon perilaku yang berbasis pada keyakinan budaya lokal, juga diperkuat dengan landasan keyakinan terhadap agama yang dianut. Keyakinan dalam beragama memberikan perspektif positif terhadap sikap individu atau masyarakat, dalam memandang penyebab bencana maupun respon terhadap berbagai permasalahan hidup pasca bencana (Aryanata dan Utami, 2019). Amawidyati dan Utami (2007) menyebutkan bahwa pada penyintas gempa Yogyakarta menunjukkan hubungan yang positif dan signifikan antara religiusitas dan kesejahteraan psikologis pasca gempa.

Faktor lain yang juga berhubungan adalah masyarakat dianggap mampu melakukan mekanisme koping adaptif untuk mengatasi gangguan stres dan kecemasan. Mekanisme koping tersebut diperkuat dengan adanya dukungan keluarga dan sosial. Penelitian oleh Sari (2016) menyebutkan lansia yang tinggal bersama keluarga menunjukkan respon koping adaptif yang lebih baik dalam menghadapi bencana kabut asap. Pola perilaku adaptif tersebut dipengaruhi perspektif individu dalam menghadapi kebencanaan dengan menggunakan psikologi positif (Aryanata dan Utami, 2019). Psikologi positif berelasi terhadap pengembangan emosi positif dan fokus pada kekuatan individu. Sehingga individu tersebut belajar untuk mengurangi stres negatif, bertahan terhadap ancaman yang nyata dan mengembangkan kesejahteraan psikologisnya (Seligman, 2013).

Faktor lain yang perlu dipertimbangkan adalah paradigma masyarakat terhadap masalah kesehatan mental. Berdasarkan Kemenkes (2019), prevalensi gangguan mental emosional dengan gejala stres dan ansietas untuk usia $>15$ tahun mencapai 9\% dari jumlah penduduk Kota Pekanbaru atau 10,45 \% 
dari jumlah penduduk Provinsi Riau. Prevalensi gangguan depresi mencapai $4,55 \%$ dari jumlah penduduk Kota Pekanbaru atau 6,63\% jumlah penduduk Provinsi Riau. Namun, cakupan pengobatan penderita depresi hanya 7,35 $\%$. Hal ini dapat disebabkan karena ketidakpatuhan berobat dan stigma sosial terhadap isu kesehatan mental.

Selain itu, dari hasil observasi yang dilakukan oleh peneliti, petugas kesehatan belum melakukan pengkajian secara komprehensif sampai pada pengkajian gangguan stres dan kecemasan pada masyarakat yang terdampak bencana kabut asap. Penelitian oleh Pane, Isturini dan Wahidin (2018) menyebutkan bahwa Kementerian Kesehatan dalam melakukan upaya penanganan permasalahan kesehatan jiwa pada korban bencana, terkendala akibat belum adanya panduan penanganan kesehatan jiwa berdasarkan jenis bencana.

Keterbatasan dalam penelitian ini yaitu peneliti menggunakan pengamatan jumlah kunjungan rawat jalan pasien RSJ Tampan dibandingkan dengan data kadar ISPU untuk memperkirakan paparan asap karhutla. Hal ini dimaksudkan untuk menerangkan risiko gangguan stres, kecemasan dan PTSD sebagai dampak adanya kebakaran hutan dan lahan. Selain itu, peneliti juga tidak melakukan pengambilan data terkait pasca bencana kabut asap. Oleh karena itu, untuk menguatkan hasil penelitian pemodelan, sebagai pengujian hasil, dapat dilakukan studi kohort oleh peneliti selanjutnya.

\section{SIMPULAN}

Berdasarkan data hasil penelitian, maka dapat ditarik kesimpulan yaitu sebagai berikut :

1. Nilai rata-rata ISPU di Kota Pekanbaru periode Juli - Oktober 2019 paling rendah bulan Oktober kategori baik dan tertinggi pada bulan September kategori berbahaya.
2. Tidak ada peningkatan kasus stres akut, kecemasan dan PTSD pada periode bencana kabut asap.

\section{SARAN}

Berdasarkan penelitian dapat disarankan beberapa hal, yaitu perlunya studi cohort lanjutan terkait dampak kebakaran hutan dan lahan terhadap resiko gangguan stres, kecemasan dan PTSD.

\section{DAFTAR PUSTAKA}

Amawidyati, SAG dan MS Utami. 2007. Religiusitas dan Psychological WellBeing pada Korban Gempa. Jurnal Psikologi 34 (2) : 164 - 176

ANTARA. 2015. Anak-anak Pekanbaru Alami Stres akibat Asap. https://m.antaranews.com/amp/berita 1524768/anak-anak-pekanbarualami-stres-akibat-asap diakses tanggal 20 April 2020

Aryanata, NT dan NMSN Utami. 2019. Meninjau Perilaku Terkait Bencana di Indonesia: Sebuah Kajian Literatur. Jurnal Psikologi Mandala 3 (1): 69 84

Badan Nasional Penanggulangan Bencana. 2019. Luas Lahan Terbakar Seluruh Indonesia Capai 857 Ribu Ha. https://www.bnpb.go.id/luas-lahanterbakar-seluruh-indonesia-capai857-ribu-ha diakses tanggal 10 Februari 2020

Badan Penanggulangan Bencana Daerah. 2019. Luas Lahan Terbakar Seluruh Indonesia Capai 857 Ribu Ha. https://www.bnpb.go.id/luas-lahanterbakar-seluruh-indonesia-capai857-ribu-ha diakses tanggal 10 Februari 2020

Daniyati, M. 2016. Pengaruh Penyajian Berita Korban Asap di Koran Republika Edisi 8 Oktober 2015 terhadap Sikap Kepedulian Sosial (Survei : Mahasiswa/I Ilmu Komunikasi UPN Veteran Jakarta). Skripsi, Universitas Pembangunan Nasional Veteran Jakarta (Tidak Diterbitkan). 
Hariyani, I. 2016. Peran Jaringan Sosial pada Kampanye Lingkungan di Media Sosial: Kasus Kampanye Melawan Asap. Kajian Ilmu Komunikasi 46 (1) : $87-100$

Hsien-Jien, T and TK Ling. 2008. Psychological and Physical Impact of the Haze Amongst a Malaysian Community (Kesan Psikologi dan Fizikal oleh Jerebu Terhadap Komuniti Malaysia). Jurnal Sains Kesihatan Malaysia 6 (2): 23 - 34

Kementerian Kesehatan. 2019. Profil Kesehatan Indonesia Tahun 2018. Kemenkes RI, Jakarta

Kementerian Lingkungan Hidup. 2019. Karhutla Monitoring Sistem. http://sipongi.menlhk.go.id diakses tanggal 25 September 2019

Kioumourtzoglou, MA., MC Power, JE Hart, OI Okereke, BA Coull, F Laden, and MG Weisskopf. 2017. The Association between Air Pollution and Onset of Depression among Middle-Aged and Older Woman. American Journal of Epidemiology 185 (9): $801-809$

Koentjoro, S dan B Andayani. 2007. Recovery Kawasan Bencana: Perwujudan Trauma Healing Melalui Kegiatan Psikologi dan Rohani. Jurnal Fakultas Hukum UII 30 (63) : 3 $-14$

Lim, Y., H Kim, JH Kim, S Bae, HY Park and YC Hong. 2012. Air Pollution and Symptoms of Depression in Elderly Adults. Environmental Health Perspective 120 (7): 1023 - 1028

Novianty, A. 2011. Penyesuaian Dusun Jangka Panjang Ditinjau dari Resiliensi Komunitas Pasca Gempa. Jurnal Psikologi 38(1): 30 - 39

Pane M., IA Isturini dan M Wahidin. 2018. Penanggulangan Krisis Kesehatan di Indonesia Tahun 2016. Media Litbangkes 28 (3): 147 - 156

Rakhman, AN dan I Kuswardani. 2012. Studi Kasus Gempa Bumi Yogyakarta 2006: Pemberdayaan Kearifan Lokal sebagai Modal
Masyarakat Tangguh Menghadapi

Bencana. Prosiding Seminar Nasional Aplikasi Sains dan Teknologi (SNAST), Yogyakarta: 3 November 2012. Hal. 185 - 193

Rozi, S. 2017. Local Wisdom and Natural Disaster in West Sumatra. El Harakah 19 (1) : 1 - 9

Rudianto. 2017. Makna Erupsi Gunung Sinabung bagi Masyarakat Desa Guru Kinayan, Kabupaten Karo. Buku Litera Yogyakarta, Yogyakarta

Sari, K. 2016. Analisa Koping Mekanisme pada Lansia di Posyandu Tanjung terhadap Kesehatan Paru Saat Terjadi Bencana Kabut Asap di Kota Pontianak Tahun 2015. Skripsi, Fakultas Kedokteran Universitas Tanjung Pura. Pontianak (Tidak Diterbitkan)

Seligman, M. 2013. Beyond Authentic Happines: Menciptakan Kebahagiaan Sempurna dengan Psikologi Positif. Mizan Pustaka. Bandung

Susanto, AD, N Arifin, S Erlang, J Zaini, F Yunus, F Fitriani, F Isbaniah, $M$ Ikhsan, Prasenohadi dan A Ginanjar. 2019. Pencegahan dan Penanganan Dampak Akibat Asap Kebakaran Hutan. UI Press, Jakarta

Suryani, AS. 2017. Pemenuhan Kebutuhan Dasar Bidang Kesehatan Lingkungan Bagi Penyintas Bencana Studi di Provinsi Riau dan Jawa Tengah. Aspirasi 8 (1): 43 - 63

Tan, BY, AZ Leong, AS Leow, NJ Ngiam, BS Ng, M Sharma, LL Yeo, PA Seow, CS Hong, YH Chee, J Chen, Z Du, LY Wong, A Batra, N Sarkar, HL Teoh RC Ho and VK Sharma. 2019. Psychosomatic Symptoms during South East Asian Haze Crisis are Related to Changes in Cerebral Hemodynamics. PLoS ONE 14 (1): 1 $-12$

Yuwanto L, HYW Tjiong, PEKV Widyakristi dan V Halim. 2018. Intervensi Psikologi Bagi Penyintas Bencana. Cerdas Pustaka Publisher, Surabaya 